\title{
DETERMINATION OF A MATHEMATICAL MODEL OF THE THIN-FILM PHOTO- VOLTAIC PANEL (CIS) BASED ON MEASUREMENT DATA
}

\section{WYZNACZANIE MODELU MATEMATYCZNEGO CIENKOWARSTWOWEGO PANELU FOTOWOLTAICZNEGO (CIS) NA PODSTAWIE DANYCH POMIAROWYCH}

\begin{abstract}
In this paper the author attempted to determine the most accurate mathematical model of the photovoltaic panel composed of a monolithic structure of series connected Copper Indium Diselenide (CIS) based solar cells, based on its actual measurement data. The purpose of this paper has been achieved by implementing the original applications which, using the methods of approximation, made it possible to design the final mathematical model of the tested panel, characterized by the minimum of error modelling. Using the known literature on the operation of similar facilities, the model parameters were determined directly from the collection of random measurement data; then the obtained models were verified by several different statistical methods. As a result, the best model was selected, based on the smallest dispersion of the theoretical values (simulated) calculated from the model relative to the actual measurements. The model will be used in practice in the future to evaluate the condition (inefficiency, use) of photovoltaic panels, what will be the theme of following articles.
\end{abstract}

Keywords: photovoltaic panel, CIS solar cells, approximation, mathematical model, statistical verification.

W artykule autor dąży do określenia, w oparciu o rzeczywiste dane pomiarowe, najbardziej dokładnego modelu matematycznego panelu fotowoltaicznego, składającego się z monolitycznej struktury połaczonych szeregowo ogniw fotowoltaicznych typu CIS. Cel pracy zostat osiagnięty poprzez wdrożenie oryginalnych aplikacji, które przy użyciu metod aproksymacji umożliwity zaprojektowanie ostatecznego modelu matematycznego badanego panelu, charakteryzującego się minimalnym błędem modelowania. Wykorzystując literaturę tematu dotycząca dziatania podobnych obiektów nieliniowych, parametry modelu zostaty określone bezpośrednio z wcześniej zarchiwizowanych losowych danych pomiarowych. Następnie uzyskane modele zweryfikowano kilkoma różnymi metodami statystycznymi. W wyniku tego wybrano najlepszy model, oparty na najmniejszej dyspersji wartości teoretycznych (symulowanych) obliczonej z modelu w stosunku do rzeczywistych pomiarów. Otrzymany model zostanie w przyszłości zastosowany w praktyce do oceny stanu (niesprawności, zużycia) paneli fotowoltaicznych, co będzie tematem kolejnych artykutów.

Stowa kluczowe: panel fotowoltaiczny, ogniwa stoneczne CIS, aproksymacja, model matematyczny, weryfikacja statystyczna.

\section{Introduction}

The subject of modelling and research of photovoltaic panels is still valid as can be seen in recent publications $[1,6,9,10]$. Modelling of photovoltaic panels during their operation is essential to control both the systems and current operational activities. An appropriate device model, determined from a certain optimal time step also makes it possible to predict the operation and any possible repairs. It also indicates the need to perform repair works.

A commonly used ideal equivalent circuit model (with three elements shown in Fig. 1) of the photovoltaic cell is shown in Fig. 1, the output current I $[\mathrm{A}]$ is as follows $[7,8,20]$ :

$$
I=I_{p h}-I_{D}=I_{p h}-I_{0}\left[\exp \left(\frac{q U}{k_{B}(T+273.15)}\right)-1\right]
$$

where: $I_{0}[\mathrm{~A}]$ - diode dark saturation current, $q$ - elementary charge $\left(1.6 \cdot 10^{-19} \mathrm{C}\right), k_{B}$ - Boltzmann constant $\left(1.38 \cdot 10^{-23} \mathrm{~J} / \mathrm{K}\right), T\left[{ }^{\circ} \mathrm{C}\right]-$ temperature.

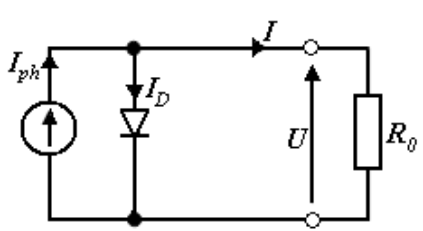

Fig. 1: An ideal equivalent circuit diagram of the photovoltaic cell for the model with three parameters $[7,8,18]: R_{0}[\Omega]$ - termination resistance, $I_{p h}[A]$ - current in the irradiated cell, $I_{D}[A]$ - current of the diode with large surface, I [A] - load current, U [V] - voltage drop on the receiver $R_{0}$

Equally often a five-element model is used, for which the equation (1) is as follows $[2,7,8]$ :

$$
I=I_{p h}-I_{0}\left\{\exp \left[\frac{q\left(U+I R_{S}\right)}{k_{B} T_{K}}\right]-1\right\}-\frac{U+I R_{S}}{R_{W}}
$$

where: $T_{K}[\mathrm{~K}]$-temperature.

An equivalent circuit diagram, corresponding to the equation (2) and including five elements of extended model, is shown in Fig. 2. 


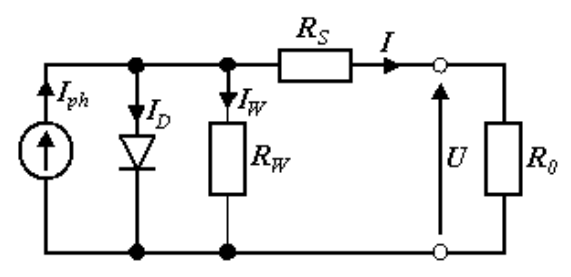

Fig. 2. An equivalent circuit diagram of the photovoltaic cell for the model with five parameters [8, 17]: $I_{W}[A]$ - current flowing through the shunt resistance

The $R_{S}$ series resistance includes contact resistance, base resistance, and the resistance of other layers of the cell. The $R_{W}$ shunt resistance represents the current leakage along the edge of the cell. When designing the cell, small $R_{S}$ values and the largest $R_{W}$ values are expected.

Implementation of an equivalent circuit diagram comes down to determining the parameters of a single solar cell, because the resultant current and voltage of photovoltaic modules (Figure 3) are (according to the Kirchoff's first and second law) sums of currents, respectively (for parallel connection), and voltage (for serial connection) of the single photovoltaic cells [3]
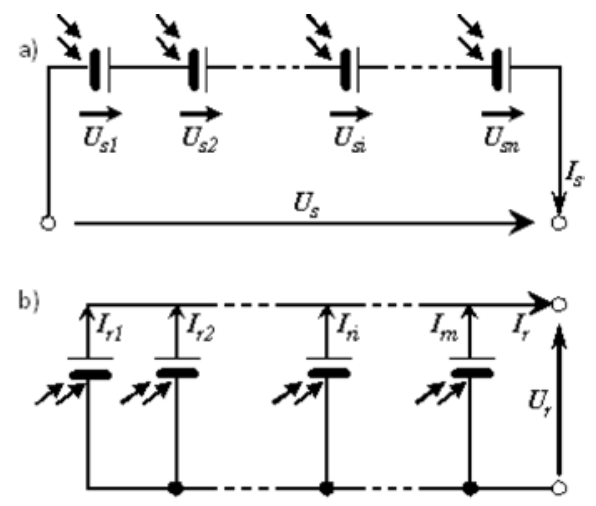

Fig. 3. a) Serial connection and b) parallel connection of the photovoltaic modules [15, 16]: $U_{s i}[V]$ - voltage at the $i$-th module which is connected in series, $I_{s}[\mathrm{~A}]$ - current of the serial connection, $U_{s}[\mathrm{~V}]$ - resultant voltage of the serial connection, $I_{r i}[A]$ - current generated in the $i$-th module which is connected in parallel, $I_{r}[A]$ - resultant current of the parallel connection, $U_{r}[V]$ - voltage of the parallel connection

\section{Materials and Methods}

\subsection{Modelling of the photovoltaic cell under actual opera- tion conditions}

The above-mentioned models from the literature do not include explicitly the essential operation parameters of the tested module. This can lead to large errors in the evaluation of the operating status of such devices. Therefore, an original equivalent circuit model of the photovoltaic cell is suggested, which contains:

- voltage at the terminals of the loaded module $-U[\mathrm{~V}]$,

- current generated by the module $-I[\mathrm{~A}]$,

- temperature of the immediate surroundings (of the air layer) around the module $-T_{K}[\mathrm{~K}]$,

- $\%$ quality of lighting on the surface of the module $-D[\%]$ (assuming uniform illumination across the entire surface of the module, which is true for solar power plants).

The temperature $T_{K}[\mathrm{~K}]$ and the quality of light $D[\%]$ (then the converted directly to the power density of visible radiation (irradiance) $D_{r}\left[\mathrm{~W} / \mathrm{m}^{2}\right]$ ) was measured using the transmitter TH-03 (Pico
Technology) sensors, respectively: EL015 (resolution $\pm 0,01^{\circ} \mathrm{C}$ ) and EL031 (resolution: $\pm 0,1 \%$,). Current $I[\mathrm{~A}]$ and the voltage $U$ [V] were measured designed by the author of a microcontroller measuring module based of PIC18F8722 microcontroller with built-in AC converter. The measurements were verified: laser / electronic thermometers, professional measure of irradiance PRC Krochmann $\mathrm{GmbH}$ and universal digital voltage and current meters. Methods and measurement equipment during the measurement modeling, verification and testing were the same.

Since the photovoltaic panels operate under variable load conditions, their mathematical models can be expressed as the following symbols:

$$
I=f\left(D, T_{K}, U\right)
$$

The process of determining the mathematical model was held under actual operation conditions of the photovoltaic panels. Due to the repeatability, modelling of the photovoltaic cell will be presented on the example of Shell ST20 panel which is composed of a monolithic structure of series connected Copper Indium Diselenide (CIS) based solar cells [14].

In order to obtain a mathematical model of the tested panel, an application written in Delphi has been designed. The algorithm of the polynomial approximation of functions of several variables was used to determine the model parameters. Sample waveforms of currentvoltage characteristics $I=f(U)$ were determined by the final application and based on the manufacturer's data [14]. The designing process of a mathematical model of the tested photovoltaic panel, due to the increasing accuracy of the model, proceeded in several stages.

At first, the ideal model was suggested, and then, after its extension and modification, the final model with the lowest $\delta r_{m}$ average relative error was proposed.

Mathematical models were determined using multivariate polynomial approximation (many variables) [4]; the detailed examples of calculation shown later in the paper relate to Shell ST20 photovoltaic panel [14].

It was found that the modelled problem is characterized by the overdetermination, which means that there is a larger number of collected measurement data than the number of parameters to set. In the present proceedings, predominance of the number of measurement data (several hundred thousand) is clear and it is purposeful, designed to obtain the most satisfactory results of the carried out search for an equivalent circuit model.

\subsubsection{Simplified model}

A simplified mathematical model is based on an ideal model with three parameters (1). It was determined from over a dozen series of measurements for different levels of lighting quality $D$, load varying from 0 to $400 \Omega$ and the variable temperature $T$ (from 20 up to $50^{\circ} \mathrm{C}$ ). Measurement intervals for $T$ and $R$ were equal: $\Delta T=1^{\circ} \mathrm{C}$ and $\Delta R=$ $10 \Omega$. Changes in lighting made it possible to obtain currents of the full range of possible values presented in the manufacturer's documentation [14].

It was assumed that any mathematical model is true for the actual parameters with values in the ranges of variation observed during the modelling process by a method of approximation [19].

For the polynomial approximation of functions of several variables the equation (4) was taken into account. Repeated test samples and different data sets with the same value of current $I$ were rejected by the approximating application.

$$
I=I_{p h}-I_{0}\left[\exp \left(\frac{B U}{(T+273.15)}\right)-1\right]=I_{p h 0} D_{r}-I_{0}\left[\exp \left(\frac{B U}{(T+273.15)}\right)-1\right],
$$


where: $I_{p h 0}\left[\mathrm{~mA} \cdot \mathrm{m}^{2} / \mathrm{W}\right]-$ parameter for short-circuit current in the irradiated cell, $D_{r}\left[\mathrm{~W} / \mathrm{m}^{2}\right]$ - power density of visible radiation (irradiance), $B[\mathrm{~K} / \mathrm{V}]$ - parameter of the simplified model which is determined empirically.

Approximating the collected measurements, the following dependence (5) was obtained. The resulting current $I$ is then expressed in $[\mathrm{mA}]$ :

$$
I=1.52 \cdot D_{r}-1.0919 \cdot 10^{-6}\left[\exp \left(\frac{325 \cdot U}{(T+273.15)}\right)-1\right]
$$

where: $I_{p h 0}=1.52 \mathrm{~mA} \cdot \mathrm{m}^{2} / \mathrm{W}, I_{0}=1.0919 \cdot 10^{-6} \mathrm{~mA}, B=325 \mathrm{~K} / \mathrm{V}$.

The average absolute error of the expressed by the formula (6) was $\Delta I_{s r}=49,6487 \mathrm{~mA}$ :

$$
\Delta I_{s r}=\frac{1}{g} \sum_{i=1}^{g}|| I-\hat{I} \mid
$$

where: $g$ - number of sample measurements during modelling, $I[\mathrm{~mA}]$ - current actual value (from the measurement), $\hat{I}[\mathrm{~mA}]$ - current value generated by the model.

The average percentage relative error, calculated according to equation (7), was $\delta I_{s r}=28,03 \%$ :

$$
\delta I_{s r}=\frac{1}{g} \sum_{i=1}^{g}\left|\frac{I-\hat{I}}{\hat{I}}\right| .
$$

It was assumed that the simplified model should be modified in order to reduce the error (7), indicating unsatisfactory accuracy to reflect the actual operation by the resulting model.

\subsubsection{Modifications of the model}

In the formula (2) $I_{p h}$ current can be expressed using the following dependence [7]:

$$
I_{p h}=I_{p h 0} D_{r}+J_{0}\left(T_{K}-T_{0}\right)
$$

where: $J_{0}[\mathrm{~A} / \mathrm{K}]$ - temperature coefficient, $T_{K}[\mathrm{~K}]$ - actual temperature of the cell operation, $T_{0}$ - reference temperature - under Standard Test Conditions (STC), i.e. when the power density of radiation is $D_{r}=1000 \mathrm{~W} / \mathrm{m}^{2}, T_{0}=298,15 \mathrm{~K}$.

Next, transformation of the expression (2) gives the following dependence:

$I=I_{p h 0} D_{r}+J_{0}\left(T_{K}-T_{0}\right)-I_{0}\left\{\exp \left[\frac{q\left(U+I R_{S}\right)}{\alpha k_{B} T_{K}}\right]-1\right\}-\frac{U+I R_{S}}{R_{W}},(9)$

where: $\alpha$-diode quality factor (for ideal photovoltaic cells $\alpha=1$, in fact usually $1<\alpha<2$ for real PV panel [19]).

Experimentally it is found that the diode quality factor $\alpha$ in polycrystalline solar cells is higher than its single crystal value, and it increases with decreasing grain size. The diode quality factor $\alpha$ increases also with increasing insulation layer thickness [5, 13]. For Shell ST20
PV Copper Indium Diselenide (CIS) panel the diode quality factor $\alpha$ is typically in the range $(1,2)$.

Assuming $R_{W}=\infty$ and $R_{S}=0$, which is not very significant error in the construction of the latest photovoltaic panels, the following model (10) is obtained. Assumption of $R_{S}=0$ might cause poor agreement between measured and calculated data in lower current exponential region (near open circuit voltage). The intention of the author was, however, obtaining the universality of the method (by performing analogous modeling measurements and evaluation of mathematical models for different geographic locations and installation arrangements). Therefore, by modifying the following mathematical models were minimized these discrepancies. Furthermore, when determining a mathematical model of any panel, some of their parameters are not known explicitly, therefore they are replaced with an additional parameter $B_{2}$ :

$$
\begin{gathered}
I=I_{p h 0} D_{r}+J_{0}\left(T_{K}-T_{0}\right)-I_{0}\left\{\exp \left[\frac{B_{2} U}{T_{K}}\right]-1\right\}, \\
B_{2}=\frac{q}{\alpha k_{B}} .
\end{gathered}
$$

However, it appears that in order to highlight the qualitative effect of temperature change on the generated current $I$, the current record $I_{0}$ can also be modified according to the formula $[7,12]$ :

$$
I_{0}=I_{d 0}\left(\frac{T_{K}}{T_{0}}\right)^{3} \exp \left[\frac{q E_{q} m_{s}}{\alpha k_{B}}\left(\frac{1}{T_{0}}-\frac{1}{T_{K}}\right)\right]
$$

where: $I_{d 0}[\mathrm{~A}]$ - diode dark current, $E_{q}[\mathrm{~V}]$ - potential energy barrier depending on the diode material, $k_{B}$ - Boltzmann constant $\left(1.381 \cdot 10^{-23} \mathrm{~J} / \mathrm{K}\right), m_{s}-$ number of cells connected in series.

Considering the still tested panel as an object of known principles of operation, but of the unknown parameters resulting from the construction and other properties, it was decided to replace a number of coefficients from the formula (13) with $B_{l}$ constant (14). After implementing all the modifications described, the following formula was obtained:

$$
I=I_{p h 0} D_{r}+J_{0}\left(T_{K}-T_{0}\right)-I_{d 0}\left(\frac{T_{K}}{T_{0}}\right)^{3} \cdot \exp \left[B_{1}\left(\frac{1}{T_{0}}-\frac{1}{T_{K}}\right)\right] \cdot\left[\exp \left(\frac{B_{2} U}{T_{K}}\right)-1\right]
$$

$$
B_{1}=\frac{q E_{q} m_{s}}{\alpha k_{B}}
$$

\subsubsection{Final model}

Based on the model (13) a symbolic form of an approximated polynomial was suggested:

$$
I=a_{1} D_{r}+a_{2} T_{1}+a_{3} T_{2} \cdot \exp \left(B_{1} T_{3}\right) \cdot\left[\exp \left(B_{2} z\right)-1\right]
$$

where: $a_{1}, a_{2}, a_{3}$ - model coefficients determined in the process of approximation, $B_{1}, B_{2}$ - the final model parameters which are selected empirically, $T_{1}, T_{2}, T_{3}, z$ - parameters calculated from the input data:

$$
a_{1}=I_{p h 0}
$$




$$
\begin{gathered}
a_{2}=J_{0}, \\
a_{2}=I_{0}, \\
T_{1}=\left(T_{K}-T_{0}\right), \\
T_{2}=\left(\frac{T_{K}}{T_{0}}\right)^{3}, \\
T_{3}=\left(\frac{1}{T_{0}}-\frac{1}{T_{K}}\right), \\
z=\frac{U}{T} .
\end{gathered}
$$

Approximation was performed for three different basis functions presented in equations (23-25). It is therefore a three-dimensional approximation of the first degree:

$$
\begin{gathered}
f_{1}\left(D_{r}\right)=D_{r}, \\
f_{2}\left(T_{K}\right)=T_{1}, \\
f_{3}\left(T_{K}, U\right)=T_{2} \cdot \exp \left(B_{1} T_{3}\right) \cdot\left[\exp \left(B_{2} z\right)-1\right] .
\end{gathered}
$$

With the approximation performed, the following parameters were obtained: $a_{l}=1.52 \mathrm{~mA}\left(\mathrm{~W} / \mathrm{m}^{2}\right)^{-1}, \quad a_{2}=-119.80 \cdot 10^{-3} \mathrm{~mA} / \mathrm{K}$, $a_{3}=-10.92 \cdot 10^{-7} \mathrm{~mA}, B_{I}=150 \mathrm{~K}, B_{2}=324 \mathrm{~K} / \mathrm{V}$. The average percentage relative error, calculated according to equation (7), was $\delta I_{s r}=14,07 \%$.

During the verification of the model $(13,15)$ unsatisfactory functioning of the $T_{2}$ (21) section was found, manifested by a worse waveform representation $I=f(U)$ for current values $I$ tending to zero. An empirical review of the solutions was made during the $T_{2}$ changes and it was decided to introduce a modified $T_{2}$ ' section. The model (15) changed its form into:

$$
\begin{gathered}
I=a_{1} D_{r}+a_{2} T_{1}+a_{3} T_{2}^{\prime} \cdot \exp \left(B_{1} T_{3}\right) \cdot\left[\exp \left(B_{2} z\right)-1\right], \\
T_{2}^{\prime}=\left(\frac{T_{C}}{T_{C 0}}\right)^{2},
\end{gathered}
$$

where: $T_{C}\left[{ }^{\circ} \mathrm{C}\right]$ - actual temperature of the cell operation, $T_{C 0}$ - reference temperature - under Standard Test Conditions (STC), i.e. when the power density of radiation is $D_{r}=1000 \mathrm{~W} / \mathrm{m}^{2}, T_{C 0}=25^{\circ} \mathrm{C}$.

With the approximation performed, the following parameters were obtained: $a_{1}=1.52 \mathrm{~mA}\left(\mathrm{~W} / \mathrm{m}^{2}\right)^{-1}, a_{2}=-119.80 \cdot 10^{-3} \mathrm{~mA} / \mathrm{K}, a_{3}=-10$ $.92 \cdot 10^{-7} \mathrm{~mA}, B_{I}=150 \mathrm{~K}, B_{2}=315 \mathrm{~K} / \mathrm{V}$. The average percentage relative error, calculated according to equation (7), was $\delta I_{s r}=13.17 \%$.

\section{Results and Discussion}

\subsection{Verification of the obtained models}

The average percentage relative error of the intermediate model after the modification (of the developed model), calculated according to the equation (15) for all the measurement samples is $\delta I_{s r}=14.07 \%$ (footnote: for the simplified model $-\delta I_{s r}=28.03 \%$ ). As can be seen, this error is twice smaller than the error obtained during the simplified modelling (10). The average percentage relative error of the final modelling (26), after having introduced a new $\mathrm{T}_{2}$ ' parameter (4.27), is $\delta I_{s r}=13.17 \%$. Detailed results of the verification are presented in Table 1 .

Table 1. Modelling errors for all measurement samples

\begin{tabular}{|c|c|c|c||}
\hline $\begin{array}{c}\text { Model type } \\
\text { Error type }\end{array}$ & $\begin{array}{c}\text { Simplified } \\
\text { model }\end{array}$ & $\begin{array}{c}\text { Developed } \\
\text { model }\end{array}$ & Final model \\
\hline$\delta I_{s r}[\%]$ & 28.033 & 14.070 & 13.174 \\
\hline$W_{k}[-]$ & 0.921 & 0.917 & 0.967 \\
\hline$F_{S}[-]$ & 1100.457 & 1043.317 & 2784.994 \\
\hline$\hat{\chi}^{2}[-]$ & 0.157 & 0.164 & 0.066 \\
\hline
\end{tabular}

Figure 4 presents examples of mapping current-voltage characteristics calculated using the final model after the modification. Maximum power point $P_{\max }$ was marked. The results were limited to the power density of radiation $D_{r}$ to approx. $600 \mathrm{~W} / \mathrm{m}^{2}$, because according to the literature $[8,11]$ these values correspond to the maximum levels of the most common levels in Poland (for locations in other latitudes should each case match the measurement ranges when calculating the mathematical model, for example, increasing the power density of radiation $D_{r}$ to approx. $1200 \mathrm{~W} / \mathrm{m}^{2}$ ). The temperature during determining the characteristics varied in the range from 25.5 up to $39.4^{\circ} \mathrm{C}$, because of the lit halogen lamps.

The curve of results obtained for $D_{r}=596 \mathrm{~W} / \mathrm{m}^{2}$ are characterized by comparable accuracy as the results shown in Figure 4 and 5 and have been taken into account in verification of the obtained models. The effect of temperature changes on the curves has been omitted because temperature changes resulted in small changes (at 5\%) near open circuit voltage.

An analysis of current-voltage characteristics, as in Figure 4, makes it possible to conclude that the various models differ mainly in their lower exponential parts. Capacities of the photovoltaic cells in this characteristics range, obtained during the operation, are much lower than the point of maximum power. However, in practice they are not so important. Also the listed average percentage values of relative errors are largely associated with these characteristics fragments. Black curves (actual measurement) are a little different from the typical I/V characteristics near $V_{\text {oc }}$ shown in the Shell ST20 data sheet [14], which could be caused by many different factors. The test panel was operated from 10 years - probably undergo the aging process (caused eg by weather conditions). It could be characterized by the presence of "hot spots" (which was not separately tested), during the measurements may exist local differences in temperature. Conditions of actual measurements were certainly different from the ideal, which are a reference to the catalog items. Moreover the author's intention was to create a method of designing a mathematical model of the real measurements (modeling) without having to know the technical details (manufacturer's data included in the application).

Similar results of the modeling for generated power as voltage are presented in Figure 5.

Sample results of errors calculation: the average relative error $\delta I_{s r}$ and comparative errors [21]: $W_{k}$ (of the multivariate correlation coefficient), $F_{S}$ (F-Snedecor test) and $\hat{\chi}^{2}$ (chi-square test) were provided 


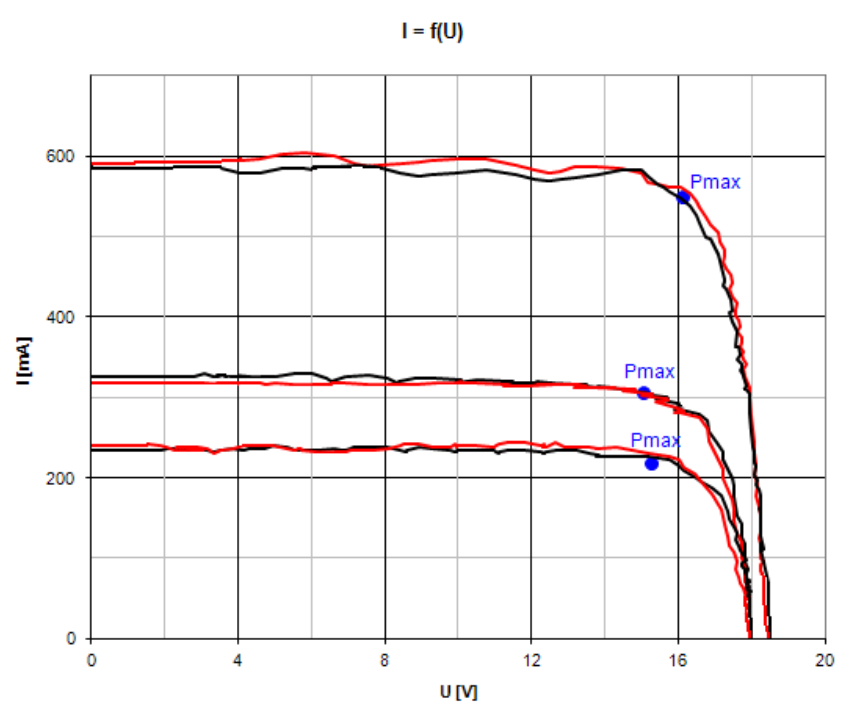

Fig. 4. Sample mapping of the characteristics $I=f(U)$ for three different levels of irradiance $D_{r}$ [15]: black curves - actual measurements, red curves - a final mathematical model after modification

$$
P=f(U)
$$

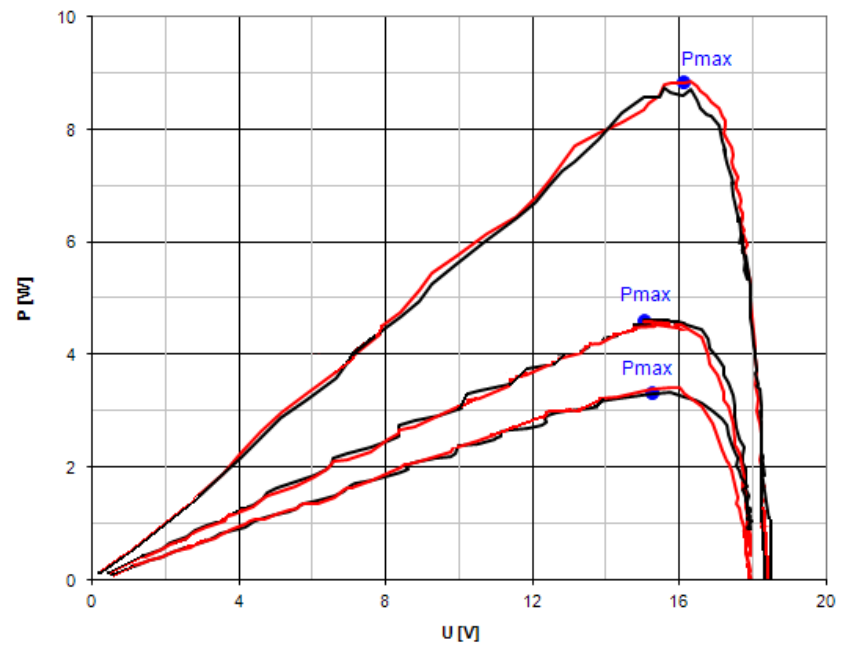

Fig. 5. Sample mapping of the characteristics $P=f(U)$ for three different levels of irradiance $D_{r}$ [22]: black curves - actual measurements, red curves - the final mathematical model after modification in Table 1. In order to show their interpretation, the values of individual indicators are placed in subsequent rows of coloured backgrounds: red - the worst, yellow - better, green - the best.

The better model is obtained during the approximation process if the $W_{k}$ parameter is closer to 1 , the $F_{S}$ parameter is greater in value and the $\hat{\chi}^{2}$ value is closer to zero. The $F_{S}$ parameter is designed to evaluate the accuracy of the $W_{k}$ multidimensional correlation coefficient, and the chi-square test $\left(\hat{\chi}^{2}\right)$ is a separate method of assessing the quality of approximation.

In the operation of photovoltaic panels working with the regulators, we seek to use them under conditions as similar as possible to the point of maximum power $P_{\max }$. Assuming the operation in the range of $\left[0,9 \cdot P_{\max }, P_{\max }\right]$ we can determine the average relative percentage errors, which provide more useful information about the effectiveness of the model under the most common conditions of their use. For example, the error value $\delta I_{s r}$ decreases then from $13,174 \%$ to $2,816 \%$.

This and similar examples show that the modelling errors $\delta I_{s r}$ in the assumed power range are much smaller than the errors determined for all samples. Thus, with the development of a mathematical model, their trend is still downward, but the decline is less steep. All the values for the obtained parameters, as in Table 1, showed the best properties of the suggested final model.

\section{Conclusion}

Modelling of the photovoltaic cells during their operation is essential for their proper maintenance. Operation conditions of such systems are, in fact, characterized by randomness; the parameters are related to each other nonlinearly. Therefore, it is necessary to include this in temporary sets of modelling data from the measurements. One of the effective methods is to use a suitable polynomial approximation of the data, including the coefficients modelling the unknown functional dependencies.

The model of the photovoltaic Copper Indium Diselenide (CIS) panel has been obtained, which satisfactorily reflects the actual operation of the photovoltaic panel, and the applied methodology can be used for any type of panel.

The model will be used in practice in the future to state assessment of photovoltaic panels (cells), what will be the theme of following articles.

\section{References}

1. Ahmad H. El Khateb, Nasrudin Abd Rahim, Jeyraj Selvaraj. Fuzzy Logic Control Approach of a Maximum Power Point Employing SEPIC Converter for Standalone Photovoltaic System. Procedia Environmental Sciences (Elsevier) 2013; 17: 529-536, https://doi.org/10.1016/j. proenv.2013.02.068.

2. Ben Salah Ch, Ouali M. Energy management of a hybrid photovoltaic system. International Journal of Energy Research 2012; 36: 130 - 138, https://doi.org/10.1002/er.1765.

3. Celik B, Gokmen N, Karatepe E, Silvestre S. Simple diagnostic approach for determining of faulted PV modules in string based PV arrays. Solar Energy 2012; 86: 3364 - 3377, https://doi.org/10.1016/j.solener.2012.09.007.

4. Dzyubenko G A, Kopotun K A, Prymak A V. Three-monotone spline approximation. Journal of Approximation Theory 2010; 162: 21682183, https://doi.org/10.1016/j.jat.2010.07.004.

5. Goel A, Sharma T P. Change in the diode quality factor with insulator layer thickness in a metal-insulator-n-semiconductor solar cell. Journal of Applied Physics 1985; 57: 2973-2974, https://doi.org/10.1063/1.335499.

6. Habbati Bellia, Ramdani Youcef, Moulay Fatima. A detailed modeling of photovoltaic module using MATLAB. NRIAG Journal of Astronomy and Geophysics 2014, 3: 53-61, https://doi.org/10.1016/j.nrjag.2014.04.001.

7. Ikegami T, Maezono T, Nakanishi F, Yamagata Y, Ebipara K. Estimation of equivalent circuit parameters of PV module and its application to optimal operation of PV system. Solar Energy 2001; 67: 389 - 395, https://doi.org/10.1016/s0927-0248(00)00307-x. 
8. Kandyda A, Rodacki T. Energy conversion in solar power (in polish). Silesian University of Technology Publisher, Gliwice, Poland 2000.

9. Krismadinata, Nasrudin Abd. Rahim, Hew Wooi Ping, Jeyraj Selvaraj. Photovoltaic Module Modeling using Simulink/Matlab. Procedia Environmental Sciences 2013; 17: 537-546, https://doi.org/10.1016/j.proenv.2013.02.069.

10. Ma Jieming, Man Ka Lok, Ting T. O., et al. Approximate Single-Diode Photovoltaic Model for Efficient I-V Characteristics Estimation. SCIENTIFIC WORLD JOURNAL 2013.

11. Pluta Z. Solar energy installations (in polish). Warsaw University of Technology Publisher, Warsaw, Poland 2003.

12. Rajapakse A. Simulation of Grid Connected Photovoltaic Systems. Cedrat News - Flux Solutions \& Mechatronic Products; Inovallée, France 2009; $57: 4$.

13. Sen K, Tyagi B P. Diode quality factor in polycrystalline solar cells. Journal of Applied Physics 1984; 56: 1240-1241, https://doi. org/10.1063/1.334059.

14. Shell Solar. Product Information Sheet - Shell ST20 Photovoltaic Solar Module. 2004.

15. Skowronek K, Trzmiel G. Analysis of selected parameters of photovoltaic modules under random operation conditions with regard to the effect of instantaneous disturbances. PELINCEC - Power Electronics and Intelligent Control for Energy Conservation, Warsaw, Poland 2005 .

16. Skowronek K, Trzmiel G. Determining the effect of faulty operation on the condition of a photovoltaic matrix. Post-conference Monograph Computer Applications in Electrical Engineering", Poznan, Poland 2006; 182 - 195.

17. Skowronek K, Trzmiel G. Generalized analysis of the effect of statistical scatter of the elements of photovoltaic matrix on its equivalent dynamic parameters by random values of darkening fields. Post-conference Monograph Computer Applications in Electrical Engineering", Poznan, Poland 2005; 238-249.

18. Skowronek K, Trzmiel G. The method for identification of fotocell in real time. ISTET - XIV International Symposium on Theoretical Electrical Engineering, Szczecin, Poland 2007.

19. Skowronek K, Trzmiel G. The model of photovoltaic cell with consideration of load variability, AMTEE - Advanced Methods of the Theory of Electrical Engineering, Cheb, Czech Republic 2009.

20. Smolinski M, Perkowski T, Mystkowski A, Dragašius E, Jastrzebski RP. AMb flywheel integration with photovoltaic system for household purpose - modelling and analysis. Eksploatacja i Niezawodnosc - Maintenance and Reliability 2017; 19 (1): 86-94, https://doi.org/10.17531/ ein.2017.1.12.

21. Taylor J R. Introduction to the analysis of measurement error. Polish Scientific Publishers PWN, Warsaw 1999.

22. Trzmiel G. Stochastic analysis of the characteristics of the photovoltaic module. PhD dissertation, Poznan University of Technology, Poland 2010.

Grzegorz TRZMIEL

Faculty of Electrical Engineering

Poznan University od Technology

Piotrowo 3A, 60-965 Poznan, Poland

E-mail: grzegorz.trzmiel@put.poznan.pl 